\title{
Hydrophobic contribution to the free energy of complexation of aromatic ligands with DNA.
}

\author{
V.V.Kostjukov, N.M. Khomutova, A.O. Lantushenko, M.P. Evstigneev
}

Sevastopol state technical university

33 Universitetskaja str., Sevastopil, Ukraine, 99053

max_evstigneev@mail.ru

\begin{abstract}
The hydrophobic component of complexation energy of double-stranded DNA with biologically active aromatic compounds was calculated using two semi-empirical methods - correlations of hydrophobic energy with changes of heat capacity $(\triangle C P)$ and solvent-accessible surface area (SASA). These surface areas were calculated for free ligands and DNA oligomers, unwound DNA duplexes and DNA-ligand complexes. The changes of polar and non-polar SASAs of molecules upon binding ligands to DNA were found. The hydrophobic contribution at both complexation stages was calculated. It was shown that the calculation of hydrophobic energy by SASA method is more correct than $(\triangle C p)$ method for DNA-binding ligands.
\end{abstract}

Keywords: double-stranded DNA, aromatic ligand, hydrophobic contribution, solvent-accessible surface area.

Introduction. Biologically active compounds (BAC), which belong to aromatic molecules, play an important role in the regulation of many significant processes in the living organism and can be widely used in clinical practice for the treatment of different diseases. As an example we can consider the group of aromatic antibiotics such as daunomycin, actinomycin $\mathrm{D}$, novantron etc, which are widely used nowadays as basic elements for chemotherapy of cancer [1]. Besides, some aromatic compounds possess significant chemotherapeutic properties. According to the literature data the mechanism of the aromatic BAC action can be explained by their immediate binding with cellular DNA or DNA-dependent proteins [2-4]. This mechanism is determined by the presence

(C) Institute of molecular biology and genetics NAS of Ukraine, 2009 in a ligand structure of a plane aromatic chromophore which provides a possibility of the molecule intercalation between the base pairs of nucleotide sequence.

It was established that stabilization of such complex occurs via stacking interactions between the ligand chromophore and adjacent base pairs of the intercalating cavity, and from the other hand, due to the intermolecular hydrogen bonding [4-6]. Stacking interactions include van der Waals [7], hydrophobic [8] and electrostatic [9] interactions. Though the thermodynamics of aromatic ligands binding with DNA has been well studied $[10,11]$, a relative contribution of above mentioned interactions into a total energy of complexation is still a subject of current discussions. The reason is a lack of common approach for the calculation of principal energy contributions into a free energy $\Delta \mathrm{G}$ of the complexation reaction between aro- 
matic ligands and DNA. Particularly, hydrophobic contribution $\Delta \mathrm{Ghp}$, which depends on releasing some water molecules, bound to DNA and the a ligand upon intercalation, is one of the most important components of the energy of complex formation with DNA. However, at present there are at least two different approaches to estimate this contribution: 1) a computation approach using molecular dynamics [12] and probabilistic methods [13]; 2) an empirical approach, based on the correlation between energy of hydrophobic solvation and change in SASA (Solvent Accessible Surface Area) $[14,15]$, or with change in $\Delta \mathrm{Cp}$ at the complexation [16]. The second approache is a routine method for estimation of hydrophobic contribution for DNA-binding aromatic ligands [11, 17], meanwhile there is still no comparative analysis of the SASA and $\Delta \mathrm{Cp}$ methods. It is noteworthy, that estimation of hydrophobic contribution during ligand intercalation into DNA molecule according by SASA method was previously done only for antibiotic daunomycin and its derivatives [17]. In the present work we have calculated hydrophobic contribution $\Delta \mathrm{Ghp}$ to the total energy of complexation of different aromatic ligands (Fig. 1) such as actinomycinD (AMD), daunomycin (DAU), nogalamycin (NOG), novantrone (NOV), ethidium bromide (EB) and proflavin (PF) with a model DNA fragment using correlation of $\Delta \mathrm{Ghp}$ with SASA and $\Delta \mathrm{Cp}$. We have also reviewed both approaches.

Materials and methods. The structures of ligands and DNA-receptor. Three-dimensional structures of the investigated ligands, presented in Fig.1, were taken from Protein Data Bank [18] (PDB IDs 1OFV, 1JO2, 1LOR, 2FUM and 1QVT correspondingly). Van der Waals radiuses of the ligand atoms correspond to AMBER 99 force field [19]. It is known that the specificity of these intercalating agents to certain DNA sequences is not very strong, but, according to the previous data [20-23], all mentioned ligands show specificity to CG- and GC-site. Taking into consideration, that DAU has more affinity to the triplet CGA-sites of DNA [20] instead of CG-dinucleotides, we used self-complementary fragment d(TCGA) flanked by $\mathrm{CG}$ from both sides as a minimal site for the ligand attachment. The self-complementary decamer d(GCGTCGACGC) 2 was used as a model fragment of DNA. Three-dimensional structure of B-DNA duplex was constructed using HyperChem 8.0 (Hypercube Inc., Canada).

The structure of complexes. During the lligands intercalation their chromophores are inserted into the central CpG-site of the duplex. Van der Waals radiuses and charges of DNA atoms in this work are correspondent to AMBER 99 force field [19]. The spatial structure of the complexes of DNA oligomers with BAC were constructed using X-PLOR, version 3.1 [24].

The complexation of intercalators with DNA could be considered as two-stage process: the formation of intercalating cavity in DNA duplex (i.e. transition of DNA helix from B-form into unwound DNA*) and the ligand insertion into unwound DNA* $[17,25]$. The formation of intercalation site was accomplished individually for each ligand moving half of the decamer atoms along the DNA helix axis on the distance $0.34 \mathrm{~nm}$ and turning them around axis through angle $\Delta \Omega$. The value of the angle $\Delta \Omega$ was equal to the value calculated during BAC intercalation into double DNA helix $[26,28]$. To make further minimization by potential energy in X-PLOR the initial structures of the ligand-DNA complexes were set on the basis of the data about the intercalation character of these molecule into DNA: it was known that AMD, DAU and EB during complexation process were inserted into CpG-site from the side of the minor groove [3, 29]; NOV and PF were inserted from the side of major groove [30]; during NOG intercalation amino sugar ring was localized in the major groove and sugar residue (nogalose) was in the minor one[29]. Optimization of the structures of the complexes was done by minimization of their potential energy using the method of conjugated gradients. The central parts of the spatial structures of DNA decamer complexes with aromatic ligands are shown in Fig.2.

Results and discussion. The calculation of hydrophobic contribution using correlation of $\Delta C h p$ with the SASA change. The hydrophobic contribution was calculated according to the expression (1) $[32,33]$, which is based on the previously proved linear correlation between energy of hydrophobic solvation of hydrocarbons and amino acids:

$$
\Delta \mathrm{Chp}=\gamma \Delta \mathrm{A},
$$



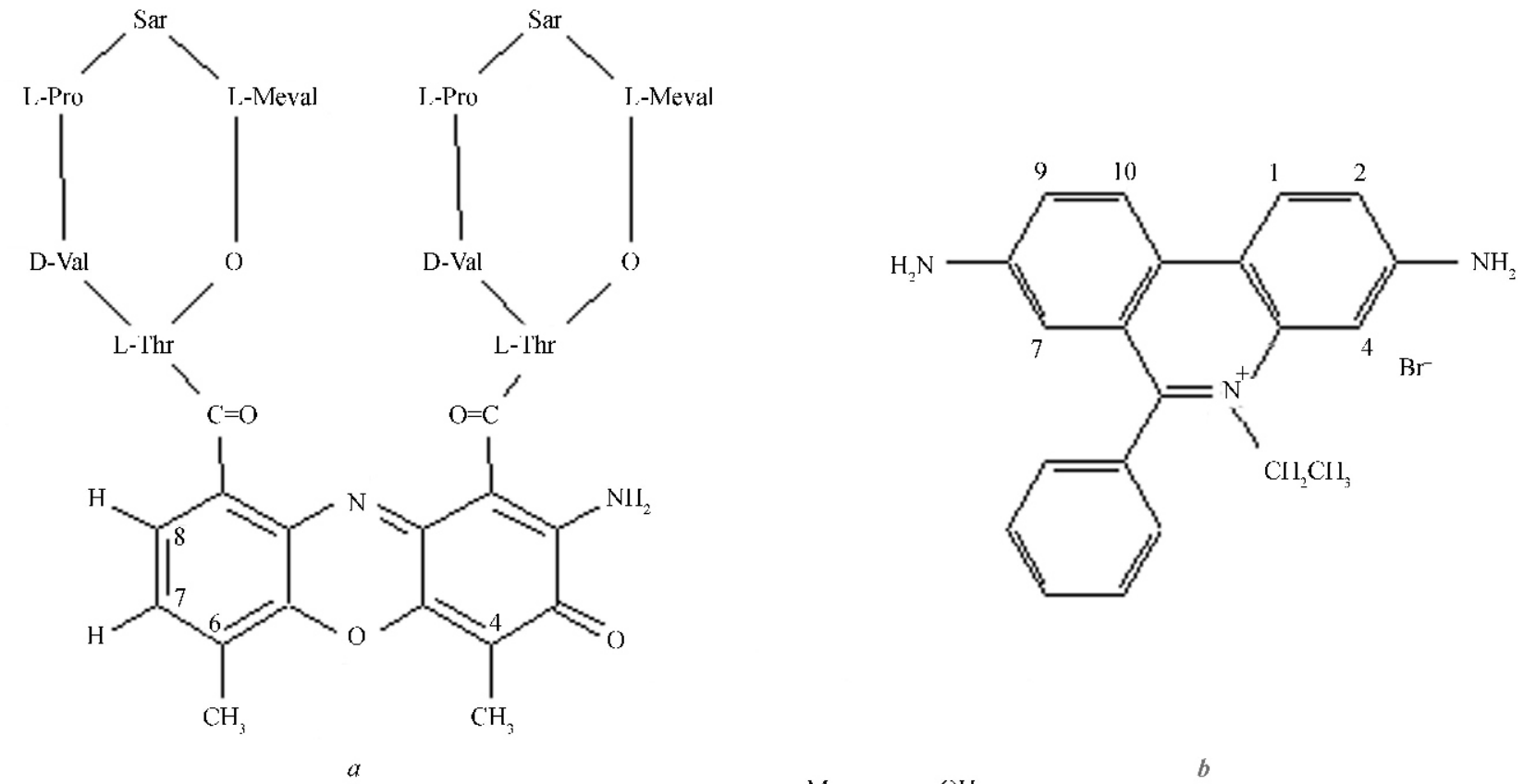

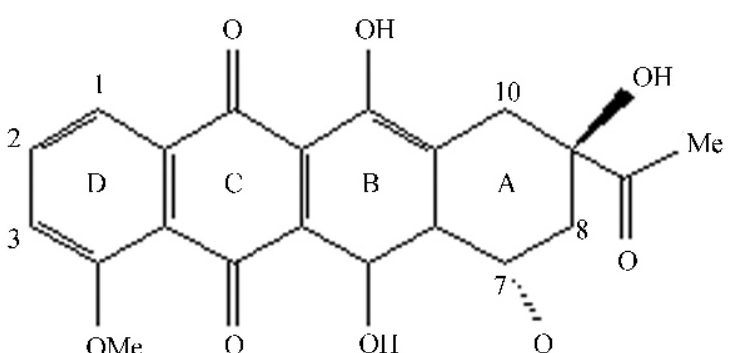<smiles>C[C@@H]1O[I]C[C@]1(N)O</smiles>

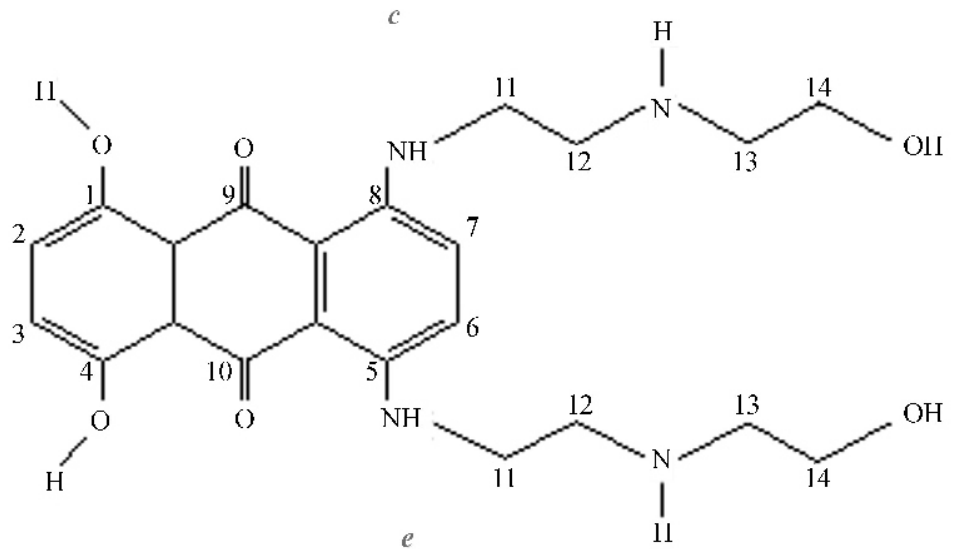

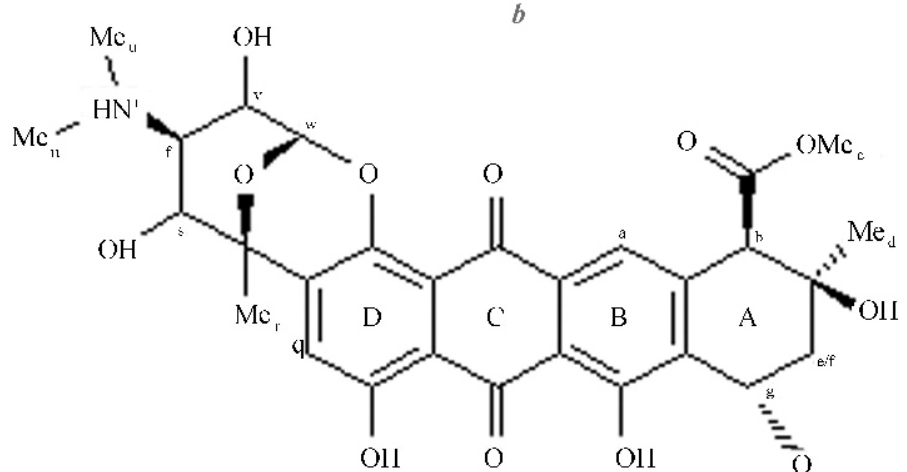

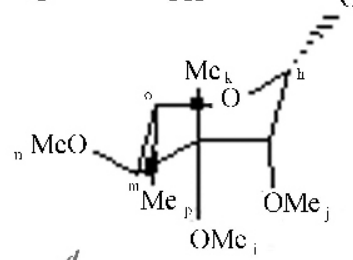<smiles></smiles>

Fig.1 Structural formulas of the investigated aromatic ligands: actinomycin D (a), ethidium bromide (b), daunomycin (c), nogalamycin (d), novantrone (e), proflavin (f). 
where $\gamma$-microscopic surface tension coefficient; $\Delta \mathrm{A}$ - the change of SASA at the stages of complexation. Some authors used the different value of $\gamma$ (see discussion in [15]), but most of them used $\gamma=50 \mathrm{cal} /\left(\mathrm{mol} \cdot \AA^{2}\right)$ for calculation of energy of protein-nucleic acid binding [33] as well as for energy of DNA nitrogen bases stacking of [34] and ligand-DNA complexes [17], considering the difference of molecular size of ligands and solvent [15]. The total SASA of the ligand-DNA complex includes Ap, polar (hydrophilic) and Anp, non-polar (hydrophobic) contributions [11]:

$$
\mathrm{A}=\mathrm{Ap}+\mathrm{Anp} ; \Delta \mathrm{A}=\Delta \mathrm{Ap}+\Delta \mathrm{Anp}
$$

where

$$
\begin{aligned}
& \Delta \mathrm{Anp}=\mathrm{Anp}(\text { complex })-\{\operatorname{Anp}(\mathrm{DNA})+ \\
& +\mathrm{Anp}(\text { free ligand })\} ;
\end{aligned}
$$

$\Delta \mathrm{Ap}=\mathrm{Ap}($ complex $)-\{\mathrm{Ap}(\mathrm{DNA})+$ $+\mathrm{Ap}($ free ligand $)\}$.

The total SASA and its contributions were calculated here using GETAREA, version 1.1 [35]. The solvent molecule (water) was presented as a sphere with radius of $0.14 \mathrm{~nm}$ (value of van der Waals radius for oxygen atom in water molecule [35]). SASA is a surface area formed by the movement of the centre of probe sphere on van der Waals surface of either solute molecules or complex [36].In turn van der Waals surface of the molecule is an assemblage of spheres with the centers coinciding with the correspondent atoms and radius values equal to van der Waals ones for the given atoms. The results of the calculations are presented in Table 1.

The calculation of hydrophobic contribution using correlation of $\Delta G h p$ with the change of heat capacity $\triangle C p$ in complexation reaction. As it was previously shown, the energy of hydrophobic solution has linear correlation with the change of heat capacity $\Delta \mathrm{Cp}$ in the complexation reaction [37]:

$$
\Delta \mathrm{Ghp}=80( \pm 10) \Delta \mathrm{Cp}
$$

The change of heat capacity also linearly correlated with the change of non-polar SASA Anp [37] or (as it was shown in the later work by the same authors [38]) with the change of polar and non-polar SASA of the protein-nucleic acids complexes. Ren J. et al. [11] carried out the correction of linear correlation $\Delta \mathrm{Ghp}$ with $\Delta \mathrm{Anp}$ and $\Delta \mathrm{Ap}$ on the basis of experimental calorimetric data for the ligand-DNA complexes as the following:

$$
\Delta \mathrm{Cp}=0.382 \Delta \mathrm{Anp}-0.121 \Delta \mathrm{Ap} .
$$

We used the expressions (5) and (6) to estimate hydrophobic contribution in complexation reaction of aromatic ligands with DNA. The calculations results are shown in Table 1.

The comparison of calculation methods of hydrophobic contribution to the energy of complexation reactions between intercalators and DNA. The calculation data of $\Delta \mathrm{Ghp}$ (see Table1) are in agreement with correspondent energies at the stage of ligand insertion EB and DAU into DNA calculated by method (5) in [11] and with the values of $\Delta \mathrm{Ghp}$ for DNA untwisting and DAU insertion by the method (5) in [17]. It gave us the basis to make a comparison between calculation methods for $\Delta \mathrm{Ghp}$ determination, which were used by different authors. The most important conclusion, which can be made after $\Delta \mathrm{G}$ comparison (see Table 1) is the following: the values of hydrophobic energy calculated by distinct methods differ by two (EB) or even ten (AMD) times! This essential difference is principal and needs to be explained.

There are three main assumptions, which are used as the base for $\Delta \mathrm{Ghp}$ calculation as the change of heat capacity (5) [31, 37-39]:

- existence of linear interrelation between enthalpy and entropy of hydrophobic dissolution or between complex formation and the change of heat capacity;

-the change of heat capacity is completely determined by hydrophobic effect;

-the change of heat capacity is linearly connected with the SASA change (see equation (6)).

The first assumption is experimentally verified for the large set of hydrocarbons and some proteins [37, 39]. The second assumption in its turn supposes negligible contribution in the change of vibration degrees of freedom, it can be indirectly proved for the reactions with protein participation [37]. And the third assump- 

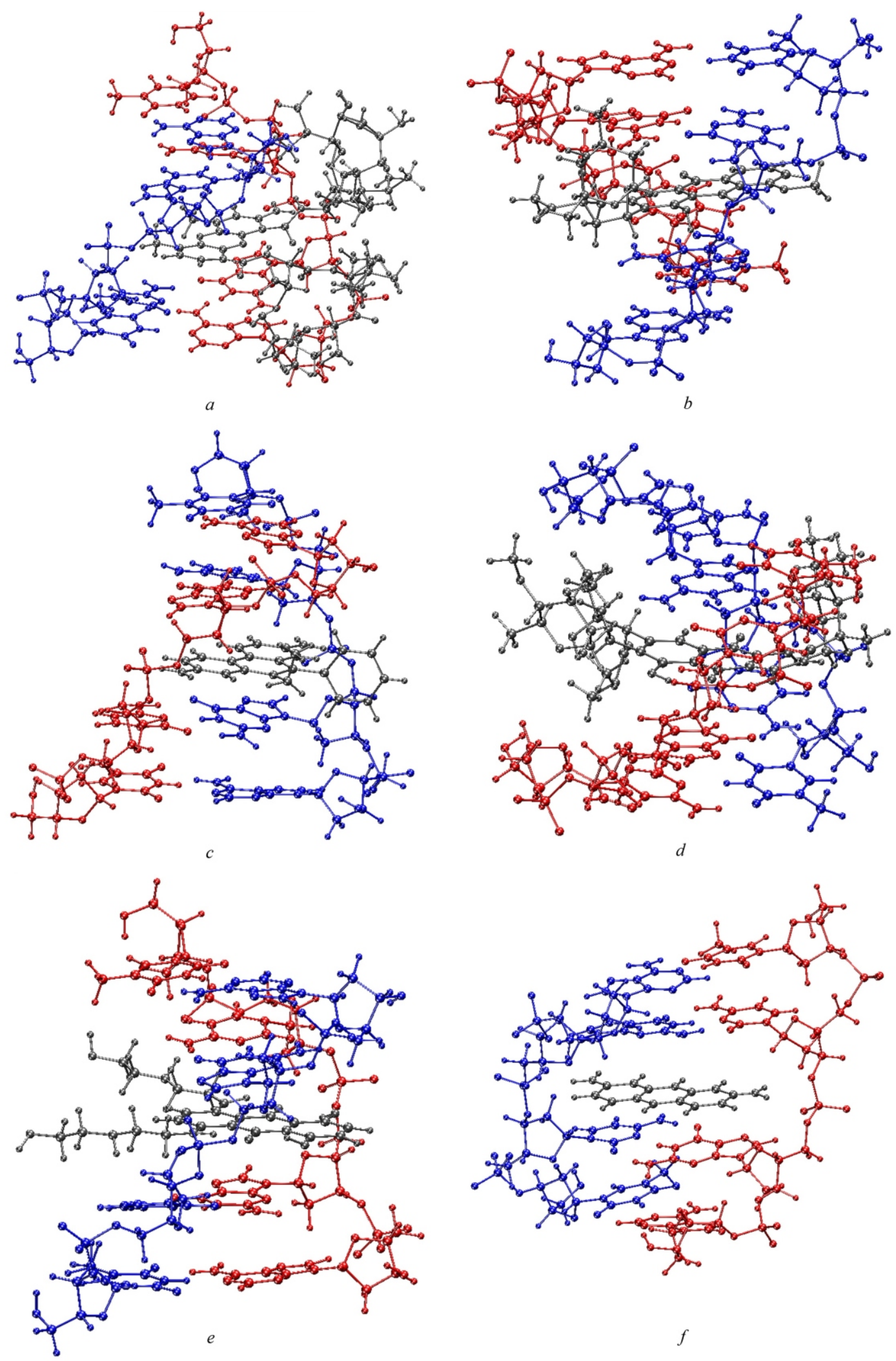

Fig.2 Central sites of calculated structures of double helical DNA with aromatic ligands such as actinomycin D (a), ethidium bromide (b), daunomycin (c), nogalamycin (d), novantrone (e), proflavin(f). 
Calculated values of the surface area of the molecules and their complexes $\left(\dot{\mathrm{A}}^{2}\right)$ and correspondent values of hydrophobic contribution $(\mathrm{kcal} / \mathrm{mol})$

\begin{tabular}{|c|c|c|c|c|c|c|c|}
\hline Ligand & Surface & $\mathrm{A}(\mathrm{L})$ & $\mathrm{A}(\mathrm{DNA})$ & \multicolumn{4}{|c|}{ DNA untwisting } \\
\hline AMD & $\begin{array}{c}\text { Polar } \\
\text { Non-polar } \\
\text { Full }\end{array}$ & $\begin{array}{c}130 \\
1203 \\
1333\end{array}$ & $\begin{array}{l}2540 \\
1523 \\
4063\end{array}$ & $\begin{array}{l}2508 \\
1890 \\
4398\end{array}$ & $\begin{array}{c}-219 \\
695 \\
476\end{array}$ & 23,4 & 23,8 \\
\hline DAU & $\begin{array}{c}\text { Polar } \\
\text { Non-polar } \\
\text { Full }\end{array}$ & $\begin{array}{l}208 \\
562 \\
770\end{array}$ & $\begin{array}{l}2540 \\
1523 \\
4063\end{array}$ & $\begin{array}{l}2664 \\
1682 \\
4347\end{array}$ & $\begin{array}{l}124 \\
159 \\
284\end{array}$ & 3,7 & 14,2 \\
\hline EB & $\begin{array}{c}\text { Polar } \\
\text { Non-polar } \\
\text { Full }\end{array}$ & $\begin{array}{c}68 \\
504 \\
572\end{array}$ & $\begin{array}{l}2540 \\
1523 \\
4063\end{array}$ & $\begin{array}{l}2658 \\
1618 \\
4277\end{array}$ & $\begin{array}{c}118 \\
96 \\
214\end{array}$ & 1,8 & 10,7 \\
\hline NOG & $\begin{array}{c}\text { Polar } \\
\text { Non-polar } \\
\text { Full }\end{array}$ & $\begin{array}{c}271 \\
741 \\
1012\end{array}$ & $\begin{array}{l}2540 \\
1523 \\
4063\end{array}$ & $\begin{array}{l}2646 \\
1617 \\
4263\end{array}$ & $\begin{array}{c}106 \\
94 \\
200\end{array}$ & 1,9 & 10,0 \\
\hline $\mathrm{PF}$ & $\begin{array}{c}\text { Polar } \\
\text { Non-polar } \\
\text { Full }\end{array}$ & $\begin{array}{l}139 \\
279 \\
419\end{array}$ & $\begin{array}{l}2540 \\
1523 \\
4063\end{array}$ & $\begin{array}{l}2655 \\
1622 \\
4278\end{array}$ & $\begin{array}{c}115 \\
99 \\
215\end{array}$ & 1,9 & 10,7 \\
\hline Ligand & Surface & & Liga & rtion & & Tota & tion \\
\hline & & $A(\mathrm{~K})$ & $\Delta A$ & $\Delta G_{c p}$ & $\Delta G_{\gamma}$ & $\Delta G_{c p}$ & $\Delta G_{\gamma}$ \\
\hline AMD & $\begin{array}{c}\text { Polar } \\
\text { Non-polar } \\
\text { Full }\end{array}$ & $\begin{array}{l}2321 \\
2218 \\
4539\end{array}$ & $\begin{array}{l}-317 \\
-875 \\
-1192\end{array}$ & $-23,7$ & $-59,6$ & $-0,3$ & $-35,8$ \\
\hline NOG & $\begin{array}{c}\text { Polar } \\
\text { Non-polar } \\
\text { Full }\end{array}$ & $\begin{array}{l}2409 \\
1746 \\
4155\end{array}$ & $\begin{array}{l}-508 \\
-612 \\
-1120\end{array}$ & $-13,8$ & $-56,0$ & $-11,9$ & $-46,0$ \\
\hline $\mathrm{NOV}$ & $\begin{array}{c}\text { Polar } \\
\text { Non-polar } \\
\text { Full }\end{array}$ & $\begin{array}{l}2536 \\
1792 \\
4328\end{array}$ & $\begin{array}{l}-334 \\
-407 \\
-741\end{array}$ & $-9,2$ & $-37,0$ & $-7,2$ & $-25,2$ \\
\hline $\mathrm{PF}$ & $\begin{array}{c}\text { Polar } \\
\text { Non-polar } \\
\text { Full }\end{array}$ & $\begin{array}{l}2530 \\
1633 \\
4163\end{array}$ & $\begin{array}{l}-265 \\
-269 \\
-534\end{array}$ & $-5,7$ & $-26,7$ & $-3,7$ & $-16,0$ \\
\hline
\end{tabular}

Note: L-ligand; C-complex; $\Delta G_{\mathrm{Cp}}, \Delta G_{\gamma}$-value of hydrophobic energy by the methods $\Delta \mathrm{C}_{\mathrm{p}}$ and SASA correspondingly.

tion, as a rule, is a result of structural thermodynamic tioned conditions are the basis for both expression (6) analysis of experimental data $[37,38]$. Above men- and the following ratio: 


$$
\Delta \mathrm{Ghp}=\Delta \mathrm{Cp}(\mathrm{T}-\mathrm{Th})-\Delta \mathrm{Cp} \mathrm{T} \ln (\mathrm{T} / \mathrm{Ts})
$$

Where $\mathrm{Th}=295 \mathrm{~K}$; Ts=386 K- the values of temperature, when the enthalpy and entropic contribution are correspondingly equal to zero $[37,39]$. If $\mathrm{T}=\mathrm{Th}$ we can get (5) from (7). As it follows from the table data and (6) the contribution of polar component in SASA change is at least three times less as compared with non-polar one. So we can neglect the second summand in (6) and, taking into consideration (5), obtain:

\section{$\Delta \mathrm{Ghp} \approx 30 \Delta \mathrm{Anp}$.}

The comparison of (8) and (2) allows to imply at least two times difference in $\Delta \mathrm{Ghp}$ determination by SASA method and $\Delta \mathrm{Cp}$ method (taking into account, that during the binding of the ligands with DNA $\Delta \mathrm{A}>\Delta \mathrm{Anp}$, as it follows from the table). So we can make a conclusion, that there is a systematic difference between two concerned methods for estimation of hydrophobic contribution of DNA-intercalating ligands. We think that there are two main reasons, according to which we can prove the incorrectness of the usage of $\Delta \mathrm{Ghp}$ calculation method based on the heat capacity change (6), (7) for DNA-intercalating ligands. In the first place as it follows from (5), the coefficient value 80 in (5) is completely determined by the values of transition temperatures Th and Ts in (7). In turn these temperature values are experimentally established for aliphatic hydrocarbons [31, 37, 39], but it is known that even for elementary aromatic groups the temperature values of Th and Ts significantly change [31]. Therefore, to make $\Delta \mathrm{Ghp}$ calculation during the binding of aromatic ligands with DNA by the method (5) we recommend the usage of the corrected coefficient value at $\Delta \mathrm{Cp}$.

Secondly, the calculation method based on heat capacity change can be correct enough only in cases when hydrophobic interactions give the main contribution into the reaction energy of solvation or complex formation (as it takes place for proteins) [37]. Under this condition the change of heat capacity is expected comparatively bigger and correlations (6), (7) are statistically significant. In the case of complex formation between intercalators and DNA the change of heat capacity is significantly less as compared with protein systems (see data [11] and [37]) and hydrophobic interactions are not completely dominated $[11,17,21]$. Besides, the contribution of vibration degrees of freedom in total value of heat capacity of the reaction is still unclear. In contrast to above mentioned method for calculation of hydrophobic contribution the SASA method (1) is based on the single assumption of linear correlation between the energy of hydrophobic dissolution of hydrocarbons and the SASA value, which is experimentally and theoretically proved $[15,34]$. The main problem of the method is a search for the correct value of $\gamma$ coefficient corresponding to the real hydrophobic contribution. Recently we have "calibrated" $\gamma$ coefficient [40] and proved the correctness of using its standard value $\gamma=50 \mathrm{cal} /\left(\mathrm{mol} \cdot \AA^{2}\right)$ for aromatic ligands. Consequently, we have carried out the analysis of hydrophobic contribution by the SASA method (see $\Delta \mathrm{G} \gamma$ in the table).

The analysis of hydrophobic contribution to the energy of complex formation between ligands and DNA. The obtained values of $\Delta \mathrm{A}$ and $\Delta \mathrm{Ghp}$ describing the binding of DNA duplex and DAU (see Table) at the both stages of intercalation are in accordance with [17]; the small difference can be explained by the fact, that in [17] the authors used van der Waals radius of the atoms corresponding to CHARMM force field. According to the table data hydrophobic advantage of the ligand binding to DNA is in the following order: $\mathrm{NOG}>\mathrm{AMD}>\mathrm{DAU}>\mathrm{NOV}>\mathrm{EB}>\mathrm{PF}$. The obtained order is in good correlation with the degree of branching of the ligand side chains: from massive molecules NOG and AMD to comparatively small PF molecule containing only two hydrophilic amino groups in 3 and 6 positions of the chromophore (see Fig. 1, f). The order is also in accordance with the decrease of hydrophobic contribution, which was shown in [11]: AMD $>$ DAU $>$ EB. The brunchness of side chains determines the efficiency of water displacement from hydration shells of DNA and ligand during the complex formation. So, more brunched side groups of intercalators inserting into DNA duplex grooves provide bigger hydrophobic contribution. The effect of water displacement is indirectly proved by the fact, that total SASA change at the stage of DNA untwisting and ligand insertion is negative (see Table). 
В. В. Костюков, Н. М. Хомутова, А. О. Лантушенко, М. П. Евстигнеев

Гидрофобный вклад в свободную энергию комплексообразования ароматических лигандов с ДНК

Резюме

Рассчитана гидрофобная составляющая энергии комплексообразования двуспиральной ДНК с биологически активными ароматическими соединениями с использованием двух полуэмпирических методик - корреляций гидрофобной энергии с изменениями теплоемкости $\left(\Delta C_{p}\right)$ и площади поверхности, доступной для растворителя (SASA). Вычислены площади данных поверхностей для свободных лигандов и олигомеров ДНК, раскрученных дуплексов ДНК и комплексов ДНК-Лиганд. Найдены изменения полярной и неполярной площадей поверхностей молекул, доступных для растворителя, при связывании лигандов с ДНК. Рассчитаны гидрофобные вклады на обоих этапах комплексообразования. Показано, что расчет гидрофобной энергии по методу SASA является более корректным, чем метод $\Delta C_{p}$, для ДНК-интеркалируюших лигандов.

Ключевые слова: двуспиральная ДНК, ароматический лиганд, гидрофобный вклад, доступная для растворителя площзадь поверхности.

\section{В. В. Костюков, Н. М. Хомутова, А. О. Лантушенко, М. П. Свстигнесв}

Гідрофобний внесок у вільну енергію комплексоутворення ароматичних лігандів з ДНК

Резюме

Розраховано гідрофобну складову енергії комплексоутворення двоспіральної ДНК з біологічно активними ароматичними сполуками з використанням двох напівемпіричних методик - кореляціий гідрофобної енергії зі змінами теплоємності $\left(\Delta C_{p}\right) \mathrm{ma}$ площі поверхні, доступної для розчинника (SASA). Обчислено пломі зазначених поверхонь для вільних лігандів та олігомерів ДНК, розкручених дуплексів ДНК $і$ комплексів ДНК-Ліганд. Знайдено зміни полярної та неполярної площ поверхонь молекул, доступних для розчинника, при зв'язуванні лігандів з ДНК. Розраховано гідрофобні внески на обох етапах комплексоутворення. Показано, щчо розрахунок гідрофобної енергії за методом SASA є коректнішим, ніж метод $\Delta C_{p}$, для лігандів, щьо інтеркалюють у ДНК.

Ключові слова: двоспіральна ДНК, ароматичний ліганд, гідрофобний внесок, доступна для розчинника площа поверхні.

\section{REFERENCES}

1. Chu E., DeVita V. T. Physicians' cancer chemotherapy drug manual.-London: Jones and Bartlett publ., 2003.-512 p.

2. Neidle S., Waring M. J. Molecular aspects of anti-cancer drug action.-London: Macmillan, 1983.-483 p.

3. Pullman B. Molecular mechanism of specifity in DNA-antitumor drug interactions // Adv. Drug Res.-1989.-18.-P. 2112.
4. Graves D. E., Velea L. M. Intercalative binding of small molecules to nucleic acids // Curr. Org. Chem.-2000.-4, N 9.P. 915-928.

5. Sartorius J., Schneider H.-J. Intercalation mechanisms with ds-DNA: binding modes and energy contributions with benzene, naphthalene, quinoline and indole derivatives including some antimalarials // J. Chem. Soc. Perkin Trans. 2.-1997.P. 2319-2327.

6. Reha D., Kabelac M., Ryjacek F., Sponer J., Sponer J. E., Elstner M., Suhai S., Hobza P. Intercalators. 1. Nature of stacking interactions between intercalators (ethidium, daunomycin, ellipticine, and 4',6-diaminide-2-phenylindole) and DNA base pairs. Ab initio quantum chemical, density functional theory, and empirical potential study // J. Amer. Chem. Soc.-2002.-124, N 13.-P. 3366-3376.

7. Kubar T., Hanus M., Ryjacek F., Hobza P. Binding of cationic and neutral phenanthridine intercalators to a DNA oligomer is controlled by dispersion energy: quantum chemical calculations and molecular mechanics simulations // Chem. Eur. J.-2006.-12.-P. 280-290.

8. Luo R., Gilson H. S. R., Potter M. J., Gilson M. K. The physical basis of nucleic acid base stacking in water // Biophys. J.2001.-80, N 1.-P. 140-148.

9. Medhi C., Mitchell J. B. O., Price S. L., Tabor A. B. Electrostatic factors in DNA intercalation // Biopolymers.-1999.52.-P. 84-93.

10. Lane A. N., Jenkins T. C. Thermodynamics of nucleic acids and their interactions with ligands // Quart. Rev. Biophys.2000.-33, N 3.-P. 255-306.

11. Ren J., Jenkins T. C., Chaires J. B. Energetics of DNA intercalation reactions // Biochemistry.-2000.-39, N 29.P. 8439-8447.

12. Meirovitch $H$. Recent developments in methodologies for calculating the entropy and free energy of biological systems by computer simulation // Curr. Opin. Struct. Biol.-2007.17.-P. 181-186.

13. Sokolov V. F., Chuev G. N. A probabilistic method for the calculation of energy of hydrophobic interactions // Biophysics.-2006.-51, N 2.-P. 207-213.

14. Lin M. S., Fawzi N. L., Head-Gordon T. Hydrophobic potential of mean force as a solvation function for protein structure prediction // Structure - 2007.-15.-P. 727-740.

15. Sharp K. A., Nicholls A., Fine R. F., Honig B. Reconciling the magnitude of the microscopic and macroscopic hydrophobic effects // Science.-1991.-252, N 5002.-P. 106-109.

16. Dill K. A., Privalov P. L., Gill S. J., Murphy K. P. The meaning of hydrophobicity // Science.-1990.-250, N 4978.P. 297-298.

17. Baginski M., Fogolari F., Briggs J. M. Electrostatic and non-electrostatic contributions to the binding free energies of anthracycline antibiotics to DNA // J. Mol. Biol.-1997.-274, N 2.-P. 253-267.

18. Berman H. M., Westbrook J., Feng Z., Gilliland G., Bhat T. N., Weissig H., Shindyalov I. N., Bourne P. E. The protein data bank // Nucl. Acids Res.-2000.-28, N 1.-P. 235-242.

19. Cheatham T. E., Cicplak P., Kollman P. A. A modified version of the Cornell et al. force field with improved sugar pucker phases and helical repeat // J. Biomol. Struct. and Dyn.-1999.-16, N 4.-P. 845-862.

20. Brana M. F., Cacho M., Gradillas A., Pascual-Teresa B., Ramos $A$. Intercalators as anticancer drugs // Curr. Pharm. Des.-2001.-7, N 17.-P. 1745-1780. 
21. Neidle S., Pearl L. H., Herzyk P., Berman H. M. A molecular model for proflavine-DNA intercalation // Nucl. Acids Res.1988.-16, N 18.-P. 8999-9016.

22. Davies D. B., Djimant L. N., Baranovsky S. F., Veselkov A. N. ${ }^{1}$ H-NMR determination of the thermodynamics of drug complexation with single-stranded and double-stranded oligonucleotides in solution: ethidium bromide complexation with the deoxytetranucleotides 5'-d(ApCpGpT), 5'-d(ApGpCpT), and 5'-d(TpGpCpA) // Biopolymers.-1997.-42, N 3.-P. 285295.

23. Snyder J. G., Hartman N. G., D'Estantoit B. L., Kennard O., Remeta D. P., Breslauer K. J. Binding of actinomycin D to DNA: Evidence for a nonclassical high-affinity binding mode that does not require GpC sites // Proc. Nat. Acad. Sci. USA.1989.-86, N 11.-P. 3968-3972.

24. Brunger A. T. X-PLOR. A system for X-ray crystallography and NMR-Yale: Univ. Press, 1992.-382 p.

25. Misra V. K., Honig B. On the magnitude of the electrostatic contribution to Ligand-DNA interactions // Proc. Nat. Acad. Sci. USA.-1995.-92, N 10.-P. 4691-4695.

26. Feigon J., Denny W. A., Leupin W., Kearns D. R. Interactions of antitumor drugs with natural DNA: ${ }^{1} \mathrm{H}$ NMR study of binding mode and kinetics // J. Med. Chem.-1984.-27, N 4.P. 450-465.

27. Waring $M$. Variation of the supercoils in closed circular DNA by binding of antibiotics and drugs: evidence for molecular models involving intercalation // J. Mol. Biol.-1970.-54, N 2.--P. 247-279.

28. Kapuscinski J., Darzynkiewicz Z., Traganos F., Melamed M. $R$. Interactions of a new antitumor agent, 1,4-dihydroxy-5,8bis[[2-[(2-hydroxyethyl)amino]-ethyl]amino]-9,10-anthrace nedione, with nucleic acids // Biochem. Pharm.-1981.-30, N 3.-P. 231-240.

29. Yang X.-L., Wang A. H.-J. Structural studies of atom-specific anticancer drugs acting on DNA // Pharm. Ther.-1999.-83, N 3.-P. 181-215.
30. Searle M. S. NMR studies of drug-DNA interactions // Progr. NMR Spectr.-1993.-25, N 5.-P. 403-480.

31. Makhatadze G. I., Privalov P. L. Energetics of protein structure // Adv. Protein Chem.-1995.-47.-P. 307-425.

32. Janin J. Angstroms and calories // Structure.-1997.-5, N 4.P. 473-479.

33. Noskov S. Yu., Lim C. Free energy decomposition of proteinprotein interactions//Biophys. J.-2001.-81,N 2.-P. 737-750.

34. Friedman R. A., Honig B. A Free energy analysis of nucleic acid base stacking in aqueous solution // Biophys. J.-1995.69, N 4.-P. 1528-1535.

35. Fraczkiewicz R., Braun $W$. Exact and efficient analytical cal$\mathrm{cu}$ lation of the accessible surface areas and their gradients for macromolecules // J. Comp. Chem.-1998.-19, N 3.-P. 319333.

36. Lee B., Richards F. M. The interpretation of protein structures: estimation of static accessibility // J. Mol. Biol.-1971.55, N 3.-P. 379-400.

37. Ha J.-H., Spolar R. S., Record M. T. Role of the hydrophobic effect in stability of site-specific Protein-DNA complexes // J. Mol. Biol.-1989.-209, N 4.-P.801-816.

38. Spolar R. S., Record M. T. Coupling of local folding to sitespecific binding of proteins to DNA // Science.-1994.-263, N 5148.-P. 777-784.

39. Baldwin R. L. Temperature dependence of the hydrophobic interaction in protein folding // Proc. Nat. Acad. Sci. USA.1986.-83, N 21.-P. 8069-8072.

40. Kostjukov V. V., Khomytova N. M., Evstigneev M. P. «Calibration» of hydrophobic contribution to the free energy of reaction of aromatic molecules complexation in solution // Russ. J. Phys. Chem. A.-2009 (in press).

UDC 577.113:577.32

Received 05.04.08 